\title{
"Drain Dance" technique for thoracoscopic application of Tissuepatch to reduce post- operative air-leak saves time and cost
}

\author{
K Ang ${ }^{*}$, I Oey, S Rathinam \\ From 23rd World Congress of the World Society of Cardio-Thoracic Surgeons \\ Split, Croatia. 12-15 September 2013
}

\section{Background}

Tissuepatch ${ }^{\mathrm{TM}}$ is an effective adjunct to reduce postoperative air-leak particularly after lung volume reduction surgery. However, thoracoscopic application of Tissuepatch ${ }^{\mathrm{TM}}$ can be time-consuming and challenging despite several modifications to the manufacturer's delivery kit. Wastage of Tissuepatch ${ }^{\mathrm{TM}}$ during its application remains a problem due to the accidental contamination and activation of the Tissuepatch ${ }^{\mathrm{TM}}$ at the tip of the delivery kit when it comes in contact with blood or tissue. We describe a new "Drain Dance" technique to apply Tissuepatch ${ }^{\mathrm{TM}}$ effectively and quickly.

\section{Method}

In brief, we had protected the tip of the delivery kit using a chest drain. This also facilitated the introduction of the delivery kit into the thorax. The chest drain cover was then removed, to allow the elegant unrolling of the Tissuepatch ${ }^{\mathrm{TM}}$ inside the chest.

\section{Results}

Using this technique in 10 patients to-date (9 unilateral and 1 bilateral procedures), the Tissuepatch ${ }^{\mathrm{TM}}$ could be applied successfully in less than 5 minutes per application. It also reduced the accidental wastage of at least one Tissuepatch ${ }^{\mathrm{TM}}$ per case.

\section{Conclusion}

The "Drain Dance" technique therefore ensures the effective thoracoscopic application of Tissuepatch ${ }^{\mathrm{TM}}$, avoiding wastage and saving time.
Published: 11 September 2013

doi:10.1186/1749-8090-8-S1-O218

Cite this article as: Ang et al:: "Drain Dance" technique for thoracoscopic application of Tissuepatch to reduce post-operative airleak saves time and cost. Journal of Cardiothoracic Surgery 2013 8(Suppl 1):0218.

* Correspondence: keng.ang@nhs.net

Dept of Thoracic Surgery, Glenfield Hospital, Leicester, UK

Submit your next manuscript to BioMed Central and take full advantage of:

- Convenient online submission

- Thorough peer review

- No space constraints or color figure charges

- Immediate publication on acceptance

- Inclusion in PubMed, CAS, Scopus and Google Scholar

- Research which is freely available for redistribution
Biomed Central 